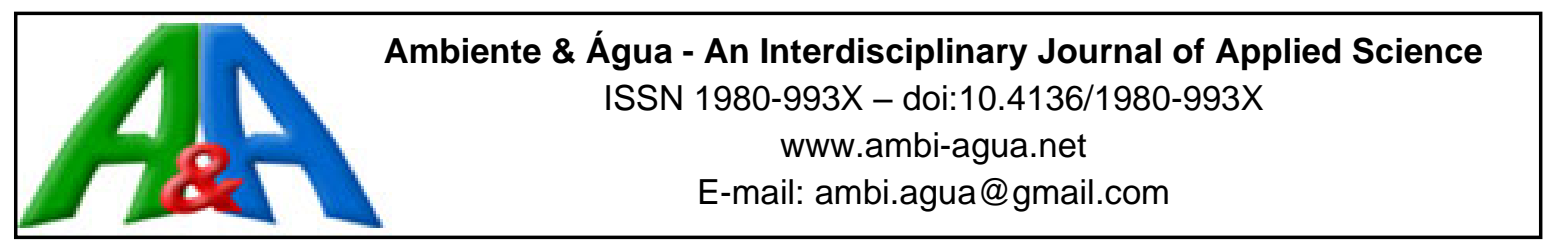

\title{
The profile and knowledge of pesticides of growers from Abaetetuba (PA)
}

\author{
ARTICLES doi:10.4136/ambi-agua.2529
}

Received: 15 Sep. 2020; Accepted: 17 Oct. 2020

\begin{abstract}
Ana Maria Cardoso ${ }^{\circledR}$; Adriana Mascarette Labinas*iD; Marcos Roberto Furlan
Programa de Pós-Graduação em Ciências Ambientais (PPGCA). Universidade de Taubaté (UNITAU), Estrada Municipal Doutor José Luiz Cembranelli, n5000, CEP: 12081-010, Taubaté, SP, Brazil. E-mail: anacardoso.nied@gmail.com,marcos.furlan@unitau.br

*Corresponding author. E-mail: alabinas@uol.com.br
\end{abstract}

\begin{abstract}
Inadequate application of phytosanitary products in agricultural production can be the result of a number of factors, from the low level of education of the applicators to the lack of training regarding the correct application of chemical pesticides. Thus, this work explored the reality of a group olericulture producers in Colônia Nova, community of Abaetetuba (PA). The methodology organized the data based on responses to a questionnaire, with structured and closed questions answered by rural owners in order to help trace the profile of pesticide applicators at that location. Among the results obtained, there was a low level of education among producers and the production of crops of condiment and leafy plants, led by scallions, cabbage, lettuce and chicory. Among the categories of pesticides used by farmers, insecticides were the most used, followed by fungicides and herbicides. No interviewed owner participated in any training for specific work with pesticides and they were also unaware of any institution that could carry out this type of training. An on-site assessment revealed that, in relation to the use of PPE, with the exception of gloves and waterproof boots, the other items were just ordinary, everyday clothes, inappropriate for this activity. Therefore, this research demonstrated the difficulty faced by the farmers of Colônia Nova, mainly due to the low level of education that prevented them from knowing the safety and legal aspects regarding the use of agricultural pesticides, the triple washing and the correct destination of empty pesticide packaging.
\end{abstract}

Keywords: environmental sciences, pesticides, phytosanitary products.

\section{O conhecimento e o perfil dos olericultores do município de Abaetetuba (PA) sobre os agrotóxicos}

\section{RESUMO}

A inadequada aplicação de produtos fitossanitários na produção agrícola pode ser resultado de uma série de fatores: desde a baixa escolaridade dos aplicadores até à ausência de oferecimento de treinamentos para a correta aplicação de defensivos químicos. Assim, o objetivo deste trabalho foi conhecer a realidade de alguns produtores de olericultura de Colônia Nova, comunidade de Abaetetuba (PA). A metodologia organizou os dados a partir da aplicação de questionário, com perguntas estruturadas e fechadas que foi respondido por proprietários rurais de forma a ajudar a traçar o perfil dos aplicadores de agrotóxicos dessa localidade. Entre os resultados obtidos, verificou-se a baixa escolaridade entre os produtores e o predomínio dos 
cultivos de plantas condimentares e folhosas, liderados pelo cheiro verde, couve, alface e chicória. Dentre as categorias de agrotóxicos utilizados pelos agricultores, os inseticidas foram os mais empregados, seguido pelos fungicidas e herbicidas. Nenhum proprietário entrevistado participou de qualquer treinamento para o trabalho específico com agrotóxicos e desconhecia, também, alguma instituição que pudesse realizar esse tipo de treinamento. Uma avaliação in loco revelou que, em relação ao uso de E.P.I, com exceção das luvas e das botas impermeáveis, os demais itens se tratavam, tão somente, de roupas comuns, do dia a dia, não sendo apropriadas para essa atividade. Portanto, nas condições desta pesquisa, ficou demonstrada a dificuldade enfrentada pelos agricultores de Colônia Nova, principalmente em função da baixa escolaridade que os impedia de conhecer aspectos legais quanto ao uso dos defensivos agrícolas, da tríplice lavagem e do destino correto das embalagens vazias de agrotóxicos.

Palavras-chave: agrotóxicos, ciências ambientais, produtos fitossanitários.

\section{INTRODUCTION}

Whenever an agricultural cultivation cycle begins, care is taken to produce a good harvest. There are many precautions: the choice of place, the selection of seeds or seedlings, equipment, supplies and the qualification and training of people who will work there. Phytosanitary products are important to protect plants from attack by pests, diseases and weeds, but they can become dangerous if used incorrectly (ANDEF, 2001).

In Brazil, the sale of pesticides to the user was conditioned on the issuance of a specific prescription, recommended by duly qualified professionals and within the limits of their professional duties, based on Federal Law No. 7,802, of July 1989. In addition, pesticides to be tried, produced, exported, imported, traded and used must be previously registered with the Ministry of Agriculture, meet the requirements of the Ministry of Health, the Ministry of Urban Development and Environment and the Ministry of Labor (Alencar, 2010).

Thus, the rural worker figures as one of the main elements of the agricultural food production chain, since the correct application of pesticides depends almost exclusively on how prepared they are, that is, on how trained these workers are. When well trained, the risks of contamination of these workers decrease substantially; however, the lack of training will make working with pesticides a risk to the health of both individual workers and the communities where they live, since, if the environment is at risk of contamination, everyone who uses it will also be subject to the same risk.

Avoidance of risks arising from pesticides must be present in all stages, that is, from the acquisition of the product, to its transport, storage, handling (especially in the preparation of the syrup), application and even the final destination of leftovers, residuals and packaging (Barroso and Wolff, 2012).

In order to ensure the protection of the health of rural workers and the correct application of chemical pesticides, the Regulatory Standard Number 31 (NR-31) was published on March $4^{\text {th }}, 2005$, bringing the criteria for the organization of the work environment in order to make compatible the planning and development of the activities of agriculture, livestock, forestry and aquaculture. According to NR-31, the rural or similar employer must provide training on technology and accident prevention with pesticides to all workers exposed directly to them.

In this way, this work had the objective of knowing, even partially, the reality of rural producers in the community of olericulture producers in Colônia Nova, Abaetetuba, Pará, regarding the use of pesticides and their socio-economic profile.

\section{MATERIALS AND METHODS}

The study was carried out from September to November of 2014, in the community of

Rev. Ambient. Água vol. 7 (supplement) - Taubaté 2020 
Colônia Nova: a rural area in the municipality of Abaetetuba, Pará. This community is located in a region known as the "road", as it is located on the margins of the state highway PA - 151.

Data collection was carried out through the application of structured questionnaires (for owners and applicators), with closed questions, according to the initial phase of the Soma Method (Albuquerque, 2000), and in the pre-test phase of the Fafram Method (Pereira, 2004).

The application of the questionnaires (after they were approved by the Research Ethics Committee) was carried out by means of scheduling and prior consent from each of the rural workers. The criteria used for the selection of the 28 properties that took part of this research were: 1) the practice of olericulture; and, 2) the use of pesticides during the productive processes.

To determine the socio-economic profile of the chemical pesticide applicator of the properties analyzed, the studies by Moura (2005), Yamashita and Santos (2009), Pereira and Pozzobon (2014) were considered.

\section{RESULTS AND DISCUSSION}

In the community of Colônia Nova (Abaetetuba - PA) 30 properties were found practicing olericulture; however, only 28 properties used pesticides at some point in the production process; so, for the specific purposes of this research, the sample universe consisted of 28 properties. In these 28 properties, only eight pesticide applicator workers (28\%) were found, as this is an activity usually performed by the farmer who owns the area (72\%). The questionnaires content sought information regarding the socio-economic profile of the applicators (owners or not) and their knowledge about issues related to pesticides.

\subsection{The rural producer applying crop protection products}

As for the level of education, the evaluation of the results indicated that, of the 28 interviewed rural landowners, $83 \%$ were literate and $17 \%$ were not; however, among the illiterate, $60 \%$ of them never attended school at any time in their lives. As for literate people, 9\% completed elementary school and 35\% completed high school; the rest interrupted or abandoned their studies. Modesto Júnior et al. (2011), working for the socio-economic diagnosis of agricultures from the Itacuruça-Alto region, also located in Abaetetuba (PA), published that $7.14 \%$ of the farmers declared themselves illiterate and $69.05 \%$ declared themselves to have elementary education, however, incomplete. Although the farmers interviewed in the Colônia Nova neighborhood worked, effectively, with olericulture, none of them stated that they had already attended, for example, technical education focused on agricultural work. There was no record for higher education, as observed by Modesto Júnior et al. (2011).

These numbers, however, are different from those of Yamashita and Santos (2009), who interviewed farmers in the district of Warta (Londrina - PR) and found that $41 \%$ had not completed elementary school, $17 \%$ had uncompleted high school, $20 \%$ had completed high school and $3 \%$ were not literate.

According to Pegado et al. (2004), in the 90's there was a significant increase in small vegetable producers in the metropolitan region of Belém, being responsible for the production of some leafy and spicy vegetables, mainly lettuce, coriander, jambu and cabbage. In the properties visited for this study, in fact, condiment and leafy plants predominated, led by the scallions (29\%), cabbage (23\%), lettuce (19\%) and chicory (17\%).

The data also revealed that there is a very small number of workers hired to act as pesticide applicators in the locality, since $72 \%$ of the properties had only one applicator in each one, and in these cases, they were the owners of the areas. This situation would indicate that most rural landowners could fall into the category of family farmers, that is, those who predominantly use family labor in the economic activities of their establishment or enterprise (Brasil, 2006). 
Among the categories of pesticides used by farmers in plantations in Colônia Nova, insecticides were the most used (64\%), followed by fungicides (35\%) and herbicides (14\%). These figures do not reflect the data released by the Agricultural Economics Institute in 2014, where the most representative category was that of herbicides, with $52.2 \%$ of marketing, followed by insecticides, with $25.5 \%$ of marketing (IEA, 2015).

The diversity of commercial pesticide brands used in Colônia Nova seems to be in line with the diversity found in Ubá - RJ, by Moura (2005), where producers used a huge variety of pesticides to control the existing pests and also those that, possibly, would come into existence.

The data revealed that $86 \%$ of the farmers stored their products next to the agricultural implements, another $7 \%$ kept them in the production greenhouse, together with the sprayers, $4 \%$ at the resale and 3\% declared that they used to store the packages of pesticides at home. Part of these data coincides with the results of Abreu et al. (2016).

Regarding the Agronomic Revenue and the invoices that, in theory, should follow the purchase of pesticides, the data showed that none of the owners kept the receipts and notes with them, indicating that, in an eventual need, the farmers could not use the information and guidance contained therein, such as, for example, the address of the place for the mandatory return of empty packaging or the guidelines for cases of poisoning.

According to current Brazilian legislation, when returning empty pesticide packages, the producer receives a delivery receipt that must be kept by the producer for inspection purposes; however, only $7.14 \%$ of the owners kept the return receipts of the empty packaging.

In the absence of training to work with pesticides, and even in the absence of an adequate level of education, $67.85 \%$ and $71.43 \%$ of the owners stated that they received the guidelines for the preparation of defensive mixtures and regulation / calibration of equipment, respectively, from friends; none of the owners received information from an agronomist and only $14.28 \%$ reported receiving the information from the resale vendors. However, it should be noted that the Technical Assistance and Rural Extension Company - Emater is present in many of the municipalities of the so-called lower Tocantins (region where Abaetetuba is located).

As concluded by Ristow et al. (2020), the recognition of the existence of risk factors for the health of rural workers comes mainly from the lack of instructions and adequate support for the use of pesticides.

The washing of the sprayer and spray nozzles seems to be a recurring activity by the owners, since $86 \%$ declared to do them right after the application. But, when changing the tip of the spray nozzles, it can be said that there is no effective practice, as only $21 \%$ declared doing it, against the $79 \%$ who declared doing the practice only when the nozzles were already damaged, which could occur around two years after the equipment was started. However, manufacturers suggest that the tips should be replaced when $10 \%$ of the total boom spray tips have a flow rate greater than or equal to $10 \%$ in relation to the nominal tip flow (Bonadio et al., 2015).

Regarding the meaning of the colored bands on the labels of the packaging of pesticides, only $12 \%$ of workers declared to know the meaning of these colored bands, which was confirmed by $10.71 \%$ of them when referring to the red banner as the one with the highest toxicological class. This result of not knowing the meaning of the colored bands is very different from that presented by Yamashita and Santos (2009) in Warta, because there, when asked about the toxicological classes, $83 \%$ of the interviewees said they knew them and the colors corresponding to each class. But it is too close to the practical result, since less than half of the respondents to the researchers (43\%) were able to match the complete color sequence. Labinas et al. (2010), investigating the degree of knowledge about the meaning of colored bands on the labels of pesticides in the region of Ribeirão Branco (SP), found that $34 \%$ of the interviewed applicators claimed to know the meaning, with $100 \%$ of these responding that the band colored red was the most dangerous; the rest, $66 \%$, said they did not know the meaning of colors on 
product labels.

According to Moura (2005), the results obtained from tomato producers in the municipality of São José de Ubá (RJ) demonstrate that the risk perception in the researched universe is socially constructed, through collective, shared knowledge, inserted in the everyday reality of common sense. However, this perception is also determined by the rural communication about pesticides established in the region under study, as well as by the producer's own subjectivity.

Regarding the reading of the pesticide label and package insert, the results revealed that only $62 \%$ performed it; $15 \%$ read every other time and $23 \%$ did not read at any time. These results were very close to the data from the Ribeirão Branco region, published by Labinas et al. (2010): 61\% read and 39\% did not read; however, they differed from the results of the municipality of Warta (PR) (Yamashita and Santos, 2009), with 47\% reading and $43 \%$ reading neither labels nor package inserts. It is possible, however, to raise some reasons that could explain the lack of reading of these very important instruments for the orientation of workers in the work with pesticides. In Warta, it was detected that an inhibiting aspect of reading could be the typographic characteristics and the legibility of the texts on labels and package inserts, and all the analyzed forms had fonts in a smaller size than indicated. Therefore, these typographic characteristics could correspond to the criterion used for the non-reading in Colônia Nova, since the font size on labels and inserts follow standard rules at national level.

Although the label and package insert are, in most cases, the only immediate guiding resource for the correct and safe handling of the chemical for farmers who do not have technical guidance, none of them declared to seek other types of information than those related to dose (43\%) and indication for use (54\%). Moura (2005), when studying 30 producers about understanding aspects of risk perception on the use of pesticides, reported that these producers only read information on the package inserts: the dose of the product to be diluted and when asked about why non-reading, some said it was because the information was too complicated for understanding; others because they have been dealing with such products for a long time, they would soon know for sure how to use them.

The collected results showed that $77 \%$ of the owners did not use any type of Personal Protective Equipment (P.P.E), which could be confirmed based on the precariousness or even the absence of clothes and shoes during the activity. Yamashita and Santos (2009), on the nonuse of P.P.E. by their interviewees, were led to conclude that the fact that these workers do not understand the risks to which they are exposed when applying such products without protective equipment demonstrates that the warnings pesticide labels and package inserts are not effective.

According to the responses obtained, the main reason alleged for not using P.P.E., on the part of $58 \%$ of the interviewees, was the lack of financial resources to obtain the equipment, followed by $19.30 \%$ for the reason of total discomfort in its use. Moura (2005) presented that only $26 \%$ of the 30 interviewees reported using P.P.E. and the reasons for not using it would be the high price and the fact that the equipment is uncomfortable and not adapted to the climatic conditions of the region. As important as having P.P.E. available and knowing how to use it, is to identify the right moments to make use of it. In the data presented by Labinas et al. (2010), the minority of workers $(45 \%)$ were concerned with adequately protecting themselves, using P.P.E. from the beginning of work with pesticides, that is, from the preparation of the syrup.

The majority of Colônia Nova applicators $(75 \%)$ revealed that they used non-washable pesticide packaging, and even those that could be taken (according to Brazilian law) were burned in their entirety; they also informed that they were unaware of any rules for the storage and return of empty pesticide packaging. According to Inpev (2016), from 2002 to 2015, the percentage of empty pesticide packaging returned by farmers increased by more than $1,200 \%$. This process represents an important way to reduce the risk of environmental contamination, as well as to protect the health of consumers and rural workers. In Brazil, Federal Laws 7,802 of 1989 and 9,974 of 2000, in addition to Decree 4,074 of 2002, determine the obligation to return 
empty pesticide packaging to resellers or manufacturers (Labinas and Araújo, 2016).

According to Santos and Labinas (2019), there is nothing compared to the reverse logistics initiative for post-consumer crop protection products like in Brazil: a worldwide reference in this segment, with more than 414 empty packaging receiving units, present in the 25 states and in the Brazilian Federal District (INPEV, 2016). Shared responsibility along the reverse logistics chain is already a Brazilian reality. However, it is necessary to invest in changing the thinking and, consequently, the behavior of individuals, making them adopt attitudes that allow compliance with the legislation and guarantee, with that, the end of the problems resulting from the misuse or incorrect destination of empty pesticide packaging.

\section{CONCLUSIONS}

It is concluded, therefore, that the rural farmers from Colônia Nova, Abaetetuba-PA, who practiced olericulture and answered the questions of this research, faced difficulties in the activity of growing vegetables due to the low level of education, which in turn prevented the reading and effective understanding of agronomic prescriptions, labels and package inserts of pesticides. The legal aspects of the use of pesticides, triple laundering and the correct destination of empty pesticide packaging, were also unknown to these farmers. The reality of the data also made it possible to detect that these farmers lacked opportunities for improvement throughout different moments in the vegetable production chain, especially with regard to training for the correct and safe use of crop protection products.

These results can be important to guide possible public policies that include literacy and specific training for the correct and safe use of pesticides.

\section{REFERENCES}

ABREU, V. S.; CORREIA, R.; NEVES, R.; SENADO, J.; SILVA, E. O uso de agrotóxicos nas propriedades de agricultores familiares do município de Tartarugalzinho, estado do Amapá. Cadernos de Agroecologia, v. 10, n. 3, 2016.

ALBUQUERQUE, C. Método Soma. Capacitação de Agricultores, Educação Sanitária, Educação Ambiental. Goiânia: Bandeirantes, 2000. 240 p.

ALENCAR, J. A. de. Normas gerais sobre o uso de agrotóxico. Sistemas de produção. 2. ed. 2010.

Available

at:

http://sistemasdeproducao.cnptia.embrapa.br/FontesHTML/Uva/CultivodaVideira_2ed/ agrotoxicos.html Access: 02 Aug. 2020.

ANDEF. Manual de uso correto e seguro de produtos fitossanitários/ agrotóxicos. Campinas: Linea Creativa, 2001. Available at: http://www.andef.com.br/manuais/ Access: 02 Aug. 2014.

BARROSO, L.; WOLFF, D. Riscos e segurança do aplicador de agrotóxicos no Brasil. Engenharia Ambiental, v. 9, n. 3, p. 087-102, 2012.

BONADIO, J. A. B.; NETO, R. A.; DA COSTA, N. V.; RAMELLA, J. R. P. Tecnologia de aplicação de defensivos agrícolas: inovações. In: KUHN, O. J. et al. (Org.). Ciências agrárias: tecnologias e perspectivas. Marechal Cândido Rondon: Universidade Estadual do Oeste do Paraná, 2015. p. 207-225.

BRASIL. Presidência da República. Lei n. 11.326, de 24 de julho de 2006. Estabelece as diretrizes para a formulação da Política Nacional da Agricultura Familiar e Empreendimentos Familiares Rurais. Diário Oficial [da] União: seção 1, Brasília, DF, 25 jul. 2006.

Rev. Ambient. Água vol. 7 (supplement) - Taubaté 2020 
INSTITUTO DE ECONOMIA AGRÍCOLA (Org.). Defensivos Agrícolas: em 2014, faturamento do segmento foi o destaque. 2015. Available at: http://www.iea.sp.gov.br/out/verTexto.php?codTexto=13679. Access: 06 Aug. 2020.

INSTITUTO NACIONAL DE PROCESSAMENTO DE EMBALAGENS VAZIAS. Reverse Logistic. São Paulo, 2016.

LABINAS, A. M.; GONDIM, H. G.; SEGANTINI, M. B.; RIBEIRO, C. C.; SANTIAGO, T. M. Avaliação do nível de conhecimento de olericultores sobre defensivos agrícolas. Horticultura brasileira, v. 28, n. 2, p.524-528, jul. 2010.

LABINAS, A. M.; ARAUJO, M. C. de. Sistema de logística reversa e o papel da supervisão governamental para a preservação da qualidade da água e do solo: o caso de embalagens vazias de pesticidas. Revista Ambiente \& Água, v. 11, n. 4, p. 759-762, 2016. https://doi.org/10.4136/ambi-agua.2000

MODESTO JUNIOR, M. S.; ALVES, R. N. B.; SILVA, E. S. A. Diagnóstico socioeconômico de comunidades de mandiocultores do Baixo Tocantins, Pará. In: CONGRESSO BRASILEIRO DE MANDIOCA, 14.; FEIRA BRASILEIRA DA MANDIOCA, 1, 2011, Maceió. Anais[...] Maceió: ABAM; SBM, 2011. p. 1-6.

MOURA, N. N. Percepção de risco do uso de agrotóxicos: o caso dos produtores de São José de Ubá/RJ. 2005. 103f. Dissertação (Mestrado em Desenvolvimento, Agricultura e Sociedade) - Instituto de Ciências Humanas e Sociais, Universidade Federal Rural do Rio de Janeiro, Rio de Janeiro, 2005.

PEGADO, D. S.; GUSMÃO, S. A. L.; VELLASCO, W.; SANTANA, S. Densidade de plantio de rúcula, em sistemas de cultivo protegido. Horticultura brasileira, v. 22, n. 2, p. 405409, 2004.

PEREIRA, R. E. A. Método de treinamento visando à mudança de comportamento dos agricultores em relação ao uso de agrotóxicos: Método Fafram. Revista Nucleus, v. 2, n. $1,2004$.

PEREIRA, L. M.; POZZOBON, C. E. Análise de riscos ambientais na aplicação de defensivos agrícolas em propriedade rural. 2014. 97f. Monografia (Especialização em Agronomia) - Universidade Regional do Noroeste do Estado do Rio Grande do Sul, Departamento de Ciências Exatas e Engenharias, Ijuí, 2014.

RISTOW, L. P.; BATTISTI, I. D. E.; STUMM, E. M. F.; MONTAGNER, S. E. D. Fatores relacionados à saúde ocupacional de agricultores expostos a agrotóxicos. Saúde e Sociedade, v. 29, n. 2, 2020. https://doi.org/10.1590/S0104-12902020180984.

SANTOS, C. V. dos; LABINAS, A. M. The pesticide applicator profile of São José dos Quatro Marcos - MT. Revista Ambiente \& Água, v. 14, n. 7, p. 1-6, 2019. http://dx.doi.org/10.4136/ambi-agua.2306

YAMASHITA, M. G. N.; SANTOS, J. E. G. Rótulos e bulas de agrotóxicos: parâmetros de legibilidade tipográfica. In: PASCHOARELLI, L. C.; MENEZES, M. DOS S. (Orgs.). Design e ergonomia: aspectos tecnológicos. São Paulo: Cultura Acadêmica, 2009. p. 197-222. 